\title{
A Case of Transoral Endoscopic Thyroidectomy Combined with Facelift Modified Radical Neck Dissection
}

\author{
Myung Jun Lee ${ }^{1}$, Mi Ra Kim ${ }^{1}$, and Jun-Ook Park ${ }^{2}$ iD \\ ${ }^{1}$ Department of Otolaryngology-Head and Neck Surgery, Haeundae Paik Hospital, Inje University College of Medicine, Busan; and \\ ${ }^{2}$ Department of Otolaryngology-Head and Neck Surgery, Eunpyeong St. Mary's Hospital, College of Medicine, The Catholic University \\ of Korea, Seoul, Korea
}

\author{
갑상선 구강내시경 수술과 안면거상 접근법을 이용한 경부 곽청술을 동시 시행한 갑상선암 1예 \\ 이명준 ${ }^{1} \cdot$ 김미라 $^{1} \cdot$ 박준욱 $^{2}$ \\ 인제대학교 의과대학 해운대백병원 이비인후과학교실, ${ }^{1}$ 가톨릭대학교 의과대학 은평성모병원 이비인후과학교실 ${ }^{2}$
}

\author{
Received May 4, 2018 \\ Revised May 31, 2018 \\ Accepted June 18, 2018 \\ Address for correspondence \\ Jun-Ook Park, MD, PhD \\ Department of Otolaryngology- \\ Head and Neck Surgery, \\ Eunpyeong St. Mary's Hospital, \\ College of Medicine, \\ The Catholic University of Korea, \\ 1021 Tongil-ro, Eunpyeong-gu, \\ Seoul 03312 Korea \\ Tel +82-2-2030-4559 \\ Fax +82-2-2030-2833 \\ E-mail junook2000@catholic.ac.kr
}

\begin{abstract}
We recently experienced a case of transoral endoscopic thyroidectomy combined with a modified radical neck dissection (MRND) using a facelift approach in a patient with keloid-prone skin. A 35-year-old female was diagnosed with a papillary thyroid carcinoma, which was 1.2 $\mathrm{cm}$ in diameter and showed level II-III lateral cervical metastases. The patient required total thyroidectomy and MRND; however, she was concerned about the neck incision because she had keloid-prone skin. We first performed a transoral, endoscopic total thyroidectomy combined with bilateral central node dissection via a tri-vestibular approach, and then followed it by MRND (II-V) using a facelift approach with the Da Vinci robotic system. We noted no significant complications, such as vocal cord palsy, hypoparathyroidism, or permanent loss of the lower lip or auricle. This new method of combining transoral and facelift approaches will be useful for patients with small thyroid cancers and lateral neck metastases.
\end{abstract}

Korean J Otorhinolaryngol-Head Neck Surg 2019;62(6):343-6

Key Words Endoscopic $\cdot$ Minimally invasive $\cdot$ Thyroidectomy $\cdot$ Transoral.

\section{Introduction}

Scars located in the middle of the neck after thyroid surgery are unacceptable to many patients, especially females. The size of the incision (and the resulting scar) is larger when such surgery is accompanied by lateral neck dissection. Recently, several authors in different countries have reported successful results after transoral thyroid surgery. ${ }^{1-4)}$ We also recently performed transoral surgery to treat thyroid cancer and reported our initial experiences. ${ }^{2,3)}$ Here we describe a

This is an Open Access article distributed under the terms of the Creative Commons Attribution Non-Commercial License (https://creativecommons.org/licenses/by-nc/4.0) which permits unrestricted non-commercial use, distribution, and reproduction in any medium, provided the original work is properly cited. case treated by transoral endoscopic thyroidectomy combined with a modified radical neck dissection, done using a facelift approach in a patient with keloid-prone skin.

\section{Case}

A 35-year-old female was admitted with a 1.2-cm-diameter papillary carcinoma in the right thyroid lobe and multiple small lateral neck metastases (level II-III), based on evaluations of aspiration cytology specimens, ultrasonography scan and neck computed tomography (Fig. 1). She had no relevant medical history and her thyroid function was normal. She had keloid-prone skin and did want her neck to be 

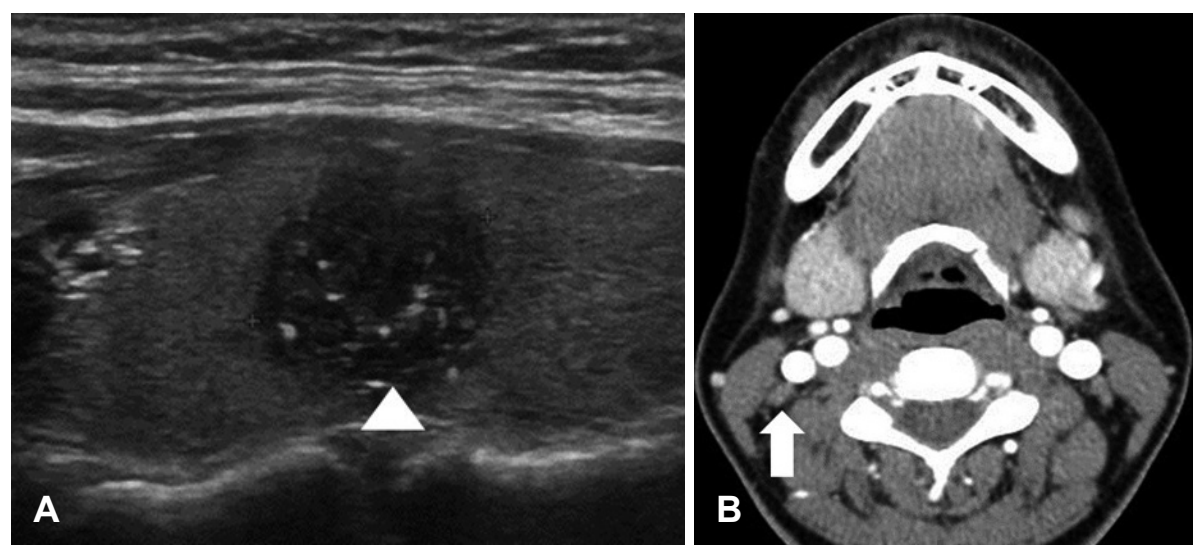

Fig. 1. Ultrasonography scan (A) revealing a $1.2-\mathrm{cm}$-diameter tumor located in the right lobe of the thyroid gland (arrowhead). Computed tomography (B) shows a metastatic lymph node at the right level II (arrow).
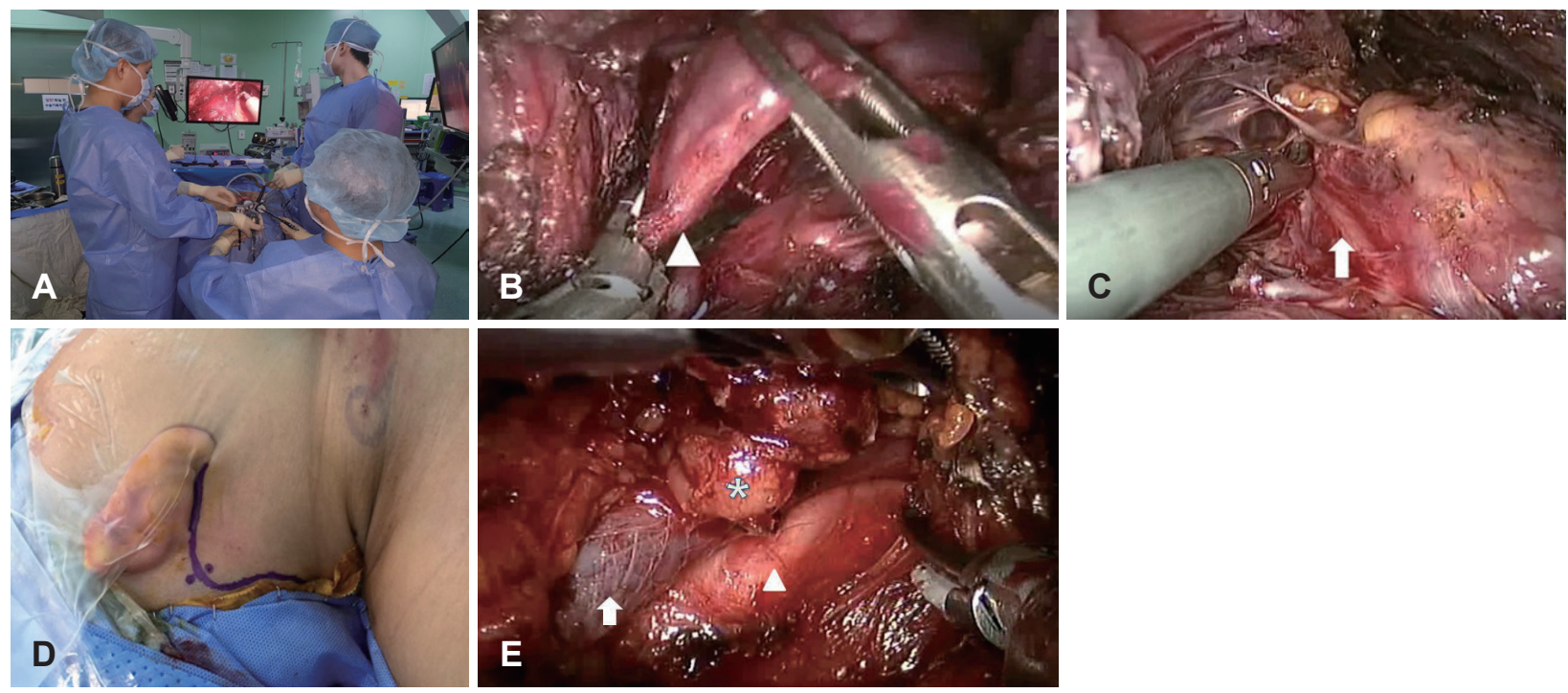

Fig. 2. The operative views at each surgical step. The operating team for transoral thyroid surgery consists of four people: the operator, two assistant surgeons, and a scrub nurse (A). The upper pole (arrowhead) was divided (B) and the recurrent laryngeal nerve (arrow) was identified during transoral total thyroidectomy (C). The facelift incision was marked along the postauricular crease and the hairline prior to modified radical neck dissection (D). The operative field taken by Da Vinci S system (Intuitive Surgical Inc., Sunnyvale, CA, USA): carotid artery (arrowhead), internal jugular vein (arrow), lymph node (asterisk) (E).
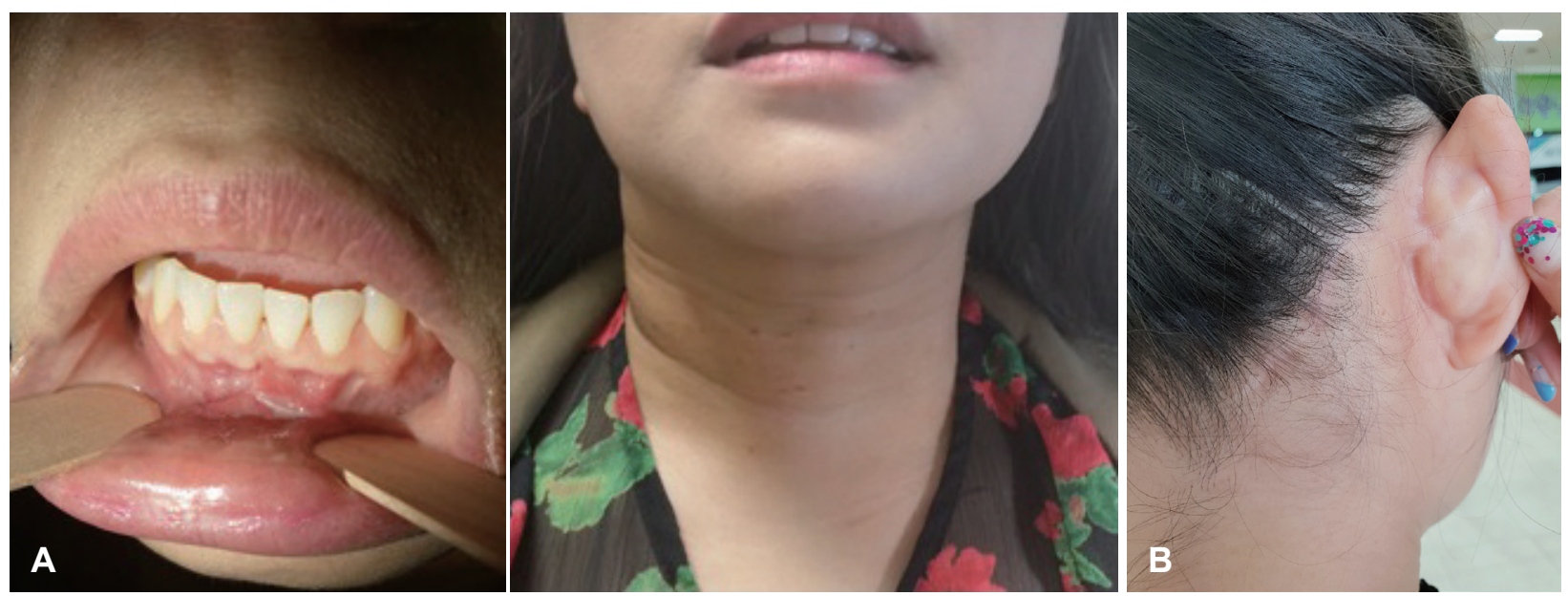

Fig. 3. Photograph of the postoperative scar. No scar was visible on the neck at 2 months after surgery, and the cosmetic outcome was good (A). Photograph of post-auricular incision line at 2 months after surgery (B). 
surgically scarred. We performed total thyroidectomy via a transoral approach with the aid of an endoscope, and modified radical neck dissection (MRND) via facelift incision using the Da Vinci S Surgical System (Intuitive Surgical Inc., Sunnyvale, CA, USA). After general anesthesia was induced via orotracheal intubation, she was placed in the supine position with a pillow under the shoulders and the neck slightly extended. We first performed transoral total thyroidectomy; all procedures were identical to those used in our previous report (Fig. 2A, B, and C). ${ }^{3)}$ A $10-\mathrm{mm}$ diameter, $30^{\circ}$ rigid endoscope (Olympus, Tokyo, Japan) was used to visualize the surgical field. All important anatomical structures, such as the recurrent laryngeal nerve, parathyroid glands, and major vessels were identified and preserved. After total thyroidectomy and central neck dissection, the neck was rotated away from the planned surgical side. A facelift incision line was created along the postauricular crease and the hairline, starting from the lower end of the crease, moving upward to the level of the external auditory canal, and crossing over to the occipital hairline (Fig. 2D). We performed MRND (II-V) via a facelift incision using the Da Vinci S system; the procedural details were similar to those of Albergotti, et al. ${ }^{5)}$ and Kim, et al. ${ }^{6}$ All important anatomical structures, such as the great auricular, vagus, spinal accessory, and phrenic nerves, the brachial plexus, and the major vessels, were identified and preserved. The total operative time was approximately 300 min. Two suction drains were placed via the oral and facelift incision sites for 4 days. The patient consumed a liquid meal without dysphagia $6 \mathrm{~h}$ after surgery, and was allowed to resume a solid diet on postoperative day 2 . She was discharged on postoperative day 7. We encountered no significant complications, such as vocal cord palsy, hypoparathyroidism, loss of the lower lip, or wound infection. A sensory change around the earlobe resolved within 1 month after surgery. Pathologically, the tumor was a $1.1 \times 0.7 \mathrm{~cm}$ papillary carcinoma with minimal extrathyroidal extension. The resection margin was negative and metastases were evident in 8 of 24 lymph nodes (ipsilateral levels II, III, IV, and VI). There was no visible neck scarring and the facial expression was normal at the 2-month follow-up (Fig. 3). The patient received high-dose $(100 \mathrm{mCi})$ radioiodine ablation (RAI) therapy after the operation and is being followed up at 9-month. The post-RAI nonsuppressed thyroglobulin level was $0.15 \mathrm{ng} / \mathrm{mL}$ and the antithyroglobulin antibody level was $17.97 \mathrm{IU} / \mathrm{mL}$.

\section{Discussion}

Thyroid cancer has a relatively good prognosis and is frequently encountered in young females who are very concerned about their quality of life after surgery, especially the cosmetic aspects thereof. Surgeons thus seek to perform 'scarless' surgery (in reality, scars are moved to sites such as the axillary and postauricular regions, where they are invisible from the side). Various approaches using the Da Vinci robotic system and endoscopic techniques have been developed. ${ }^{7,8)}$ Terris and Singer ${ }^{7)}$ and Terris ${ }^{8)}$ developed a facelift approach for robotic thyroid lobectomy appropriate; this approach reduces the area dissected and allows head-and -neck surgeons to work with a familiar anatomy. Albergotti, et al. ${ }^{5)}$ and Kim, et al. ${ }^{6}$ recently described the safety and utility of robot-assisted neck dissection using a facelift approach. ${ }^{5,6)}$ Until recently, we also performed robotic or endoscopic thyroid surgery via a facelift approach, but changed to transoral endoscopic surgery in 2016. ${ }^{9,10)}$ The principal limitations of the facelift approach are the poor surgical view and lack of space in which to safely resect the contralateral thyroid lobe. The anterior protrusions of the cricoids, trachea, and thyroid cartilage block the line of sight, creating a blind spot in the region of the contralateral superior pole and the retrothyroidal area. Therefore, when performing total thyroidectomy, facelift incisions should be made on both sides. This renders the procedure more invasive and lengthens the operative time. The transoral approach is more efficient; the endoscope and the instruments are inserted in the middle of the mouth but it can be difficult to access the upper lateral neck. Thus, we combined the transoral approach for total thyroidectomy with central node dissection, and the facelift approach for MRND, to eliminate the drawbacks of the two techniques. In principle, a thyroid carcinoma accompanied by cervical metastasis should be treated via open surgery, but our new technique will be useful in selected cases (such as our present patient with keloid-prone skin) with a small papillary thyroid cancer and lateral neck metastases.

\section{Acknowledgments}

This work was supported by the National Research Foundation of Korea (NRF) grant funded by the Korea government (No. NRF2014R1A2A2A03004802).

\section{ORCID}

Jun-Ook Park https://orcid.org/0000-0001-7118-3463 


\section{REFERENCES}

1) Anuwong A. Transoral endoscopic thyroidectomy vestibular approach: a series of the first 60 human cases. World J Surg 2016;40(3):491-7.

2) Park JO, Kim MR, Kim DH, Lee DK. Transoral endoscopic thyroidectomy via the trivestibular route. Ann Surg Treat Res 2016; 91(5):269-72.

3) Park JO, Sun DI. Transoral endoscopic thyroidectomy: our initial experience using a new endoscopic technique. Surg Endosc 2017;31 (12):5436-43.

4) Lee HY, You JY, Woo SU, Son GS, Lee JB, Bae JW, et al. Transoral periosteal thyroidectomy: cadaver to human. Surg Endosc 2015;29(4): 898-904.

5) Albergotti WG, Byrd JK, Nance M, Choi EC, Koh YW, Kim S, et al. Robot-assisted neck dissection through a modified facelift incision.
Ann Otol Rhinol Laryngol 2016;125(2):123-9.

6) Kim WS, Byeon HK, Park YM, Ha JG, Kim ES, Koh YW, et al. Therapeutic robot-assisted neck dissection via a retroauricular or modified facelift approach in head and neck cancer: a comparative study with conventional transcervical neck dissection. Head Neck 2015;37(2):249-54.

7) Terris DJ, Singer MC. Robotic facelift thyroidectomy: facilitating remote access surgery. Head Neck 2012;34(5):746-7.

8) Terris DJ, Singer MC, Seybt MW. Robotic facelift thyroidectomy: II. clinical feasibility and safety. Laryngoscope 2011;121(8):1636-41.

9) Park JO, Kim SY, Chun BJ, Joo YH, Cho KJ, Park YH, et al. Endoscope-assisted facelift thyroid surgery: an initial experience using a new endoscopic technique. Surg Endosc 2015;29(6):1469-75.

10) Park JO. Facelift approach for resecting benign upper neck masses. World J Surg 2017;41(6):1488-93. 